\title{
PENDEKATAN KONSTRUKTIVISTIK MELALUI METODE LEARNING CYCLE UNTUK MENINGKATKAN PENGUASAAN KONSEP FISIKA PADA MATAKULIAH ASTROFISIKA
}

\author{
Mislan Sasono $^{1)}$, Pujianto ${ }^{2)}$ \\ ${ }^{1}$ Pendidikan Fisika FPMIPA \\ IKIP PGRI Madiun \\ Email: mislan_fis03@yahoo.com \\ ${ }^{2}$ Pendidikan Fisika FMIPA \\ Universitas Negeri Yogyakarta \\ Email:puji_uny@yahoo.com
}

\begin{abstract}
ABSTRAK
Penelitian ini bertujuan untuk: 1) mendapatkan langkah-langkah penerapan pendekatan konstruktivistik melalui metode learning cycle yang dapat mengaktifkan mahasiswa dalam proses belajar mengajar dan 2) mengetahui apakah pendekatan konstruktivistik melalui metode learning cycle dapat membantu mahasiswa dalam meningkatkan penguasaan konsep fisika pada matakuliah astrofisika. Penelitian ini dilakukan berdasarkan observasi dan permasalahan yang terjadi pada mahasiswa fisika IKIP PGRI Madiun yang mengikuti matakuliah astrofisika.

Metode yang digunakan adalah penelitian tindakan kelas (Classroom Action Research) dengan subjek penelitian mahasiswa semester III yang mengikuti matakuliah astrofisika. Penelitian ini dilakukan dalam tiga siklus dan setiap siklus terdiri dari rencana, tindakan, observasi, serta refleksi.

Hasil penelitian menunjukkan bahwa siklus ketiga adalah tindakan paling efektif jika dibandingkan dengan siklus yang lain. Tahap-tahap metode learning cycle pada siklus ketiga dapat mengaktifkan mahasiswa dalam proses pembelajaran fisika. Penerapan pendekatan konstruktivistik melalui metode learning cycle dapat meningkatkan penguasaan konsep fisika pada mahasiswa.
\end{abstract}

Kata Kunci: Pendekatan Konstruktivistik, Metode Learning Cycle, Penguasaan Konsep Fisika.

\section{PENDAHULUAN}

Seiring perkembangan zaman, kebutuhan manusia semakin meningkat pula. Untuk memenuhi kebutuhan tersebut, para ilmuwan memajukan ilmu pengetahuan dan teknologi (IPTEK). Setiap negara berusaha semaksimal mungkin untuk meningkatkan IPTEK bangsanya. Tingkat penguasaan IPTEK yang dicapai oleh suatu bangsa biasanya dipakai sebagai tolak ukur kemajuan bangsa itu. Seperti diketahui, dalam bidang IPTEK negara kita masih jauh ketinggalan dengan negaranegara yang telah maju.

Salah satu cara untuk menyiapkan para calon pakar IPTEK, yaitu pendidikan fisika harus dibenahi dan ditangani secara serius, sehingga banyak mahasiswa merasa tertarik pada mata pelajaran fisika, untuk kemudian menekuni dan menguasainya secara tuntas.
Untuk menuju kesana pemerintah telah melakukan berbagai upaya, salah satunya membenahi Kurikulum.

Kenyataan yang terjadi di lapangan, dosen cenderung dominan dalam mengajarkan konsep atau materi perkuliahan di kelas, mahasiswa semakin tergantung pada inisiatif dosen (Munjid Nur Alamsyah, 2003: 1). Semua kegiatan kelas berpusat pada dosen. Jika keadaan ini berlangsung dari hari ke hari, maka upaya peningkatan kualitas pembelajaran terasa tidak mengalami pergeseran. Dalam situasi pembelajaran yang berlangsung secara monoton, mahasiswa merasa bosan dan bahkan seperti di penjara, dan pada akhirnya suasana pembelajaran akan semakin menyiksa.

Di dalam Kurikulum, mahasiswa dituntut untuk aktif dalam kegiatan belajar 
mengajar. Namun berdasarkan observasi awal dapat diungkapkan bahwa kegiatan belajar mengajar astrofisika di IKIP PGRI Madiun, secara umum berlangsung klasikal dengan kegiatan yang bersifat informatif. dosen menggunakan metode ceramah yang lebih menekankan pada komunikasi satu arah. Metode pembelajaran yang digunakan dosen untuk merangsang siswa aktif dalam proses pembelajaran seperti demonstrasi, diskusi, dan eksperimen jarang dilakukan. Selain itu dosen juga jarang menggunakan media pembelajaran untuk membantu mahasiswa menemukan konsep fisika yang sedang dipelajari, seperti LKM. Penyampaian materi yang bersifat informatif, menyebabkan siswa kurang aktif dalam mengembangkan ide-ide yang mereka miliki sehingga menimbulkan kejenuhan mahasiswa ketika mengikuti proses pembelajaran fisika. Situasi mahasiswa di kelas pada saat proses pembelajaran astrofisika ditemukan adanya permasalahan mengenai kurangnya aktivitas mahasiswa. mahaiswa lebih banyak mendengar, mencatat, dan memperhatikan dosen sehingga aktivitas mahasiswa tergantung pada guru.

Hal ini disebabkan oleh beberapa faktor antara lain:

1. Tuntutan target kurikulum yang harus dipenuhi, sedangkan waktu hanya cukup untuk penyampaian materi secara informatif.

2. Pembelajaran fisika dengan praktikum atau diskusi-diskusi memerlukan waktu yang sangat lama, mulai dari persiapan sampai pelaksanaan.

Dari hal tersebut di atas, kegiatan pembelajaran, khususnya astrofisika, hendaknya lebih diarahkan pada kegiatan yang mendorong mahasiswa belajar aktif, baik secara fisik, sosial, maupun psikis. Proses pembelajaran perlu dilakukan dengan tenang dan menyenangkan, hal tersebut tentu saja menuntut aktivitas dan kreativitas dosen dalam menciptakan lingkungan yang kondusif. Metode dan strategi belajar-mengajar yang kondusif untuk hal tersebut perlu dikembangkan. Untuk mempelajari konsep digunakan pendekatan, metode dan evaluasi yang tepat, sehingga proses menjadi bermakna bagi mahasiswa.

Sebuah solusi yang bisa ditawarkan atas masalah di atas, yaitu dengan menyiapkan mahasiswa menjadi anak yang adaptif. Hal ini menekankan pada kemampuan mahasiswa untuk menerapkan apa yang telah mereka pelajari pada situasi lain yang beragam dalam kehidupan seharihari. Menurut Vernon A. Magnesen sebagaimana yang disebutkan oleh Gordon dan Jeannette (2000: 100), hakikatnya kita belajar $10 \%$ dari apa yang kita baca, $20 \%$ dari apa yang kita dengar, 30\% dari apa yang kita lihat, 50\% dari apa yang kita lihat dan dengar, $70 \%$ apa yang kita katakan, dan $90 \%$ dari apa yang kita katakan dan lakukan. Oleh karena itu, kelas yang semula berpusat pada dosen harus diubah menjadi kelas yang berpusat pada mahasiswa dan alternatif yang banyak ditemukan akhirakhir ini adalah melalui pendekatan konstruktivistik.

Kegiatan pembelajaran dengan pendekatan konstruktivistik, mengajar bukanlah kegiatan memindahkan pengetahuan dari dosen ke mahasiswa, melainkan suatu kegiatan yang memungkinkan membangun sendiri pengetahuannya. Mengajar berarti partisipasi dengan pelajar dalam membentuk pengetahuan membuat bermakna, mencari kejelasan, bersikap kritis dan mengadakan justifikasi. Pada situasi itu dosen tidak akan bersikap menggurui, dosen hanya sebagai fasilitator. Aktivitas kelas akan berpusat pada mahasiswa. Mahasiswa cenderung akan mengajukan banyak pertanyaan, melakukan eksperimen, membuat analogi-analogi baru sampai pada membuat kesimpulan atau generalisasi sendiri.

Learning cycle atau daur belajar pengalaman yaitu sebuah metode pembelajaran yang mendasarkan pada pendekatan konstruktivistik. Learning cycle merupakan sebuah metode pembelajaran yang menuntut mahasiswa untuk terlibat secara langsung dan aktif dalam proses pembelajaran. Siswa diberi kesempatan seluas-luasnya untuk mengungkapkan perasaan dan hasil pemilihannya tanpa ada 
rasa tertekan, sehingga diharapkan dapat menciptakan pembelajaran yang produktif dan bermakna, tanpa mengubah tatanan yang ada.

Metode pembelajaran learning cycle dalam pelaksanaannya dapat dikombinasikan dengan metode lain. Kombinasi ini diharapkan dapat lebih mengaktifkan mahasiswa untuk menemukan sendiri pemahaman konsep, maupun sikap yang mahasiswa butuhkan. Bertolak dari hal tersebut, maka peneliti ingin mengetahui optimalisasi pembelajaran astrofisika dengan pendekatan konstruktivistik melalui metode learning cycle yang dikombinasikan dengan metode lain.

\section{METODE PENELITIAN}

Penelitian ini bertujuan untuk menerapkan pendekatan konstruktivistik melalui metode learning cycle dalam rangka meningkatkan penguasaan konsep fisika khususnya pokok astrofisika, pada siswa kelas IIIA IKIP PGRI Madiun. Pada penelitian ini digunakan desain penelitian tindakan kelas (classrom action research).

Menurut Elliot, seperti dikutip Suwarsih Madya (1994: 1), yang dimaksud dengan penelitian tindakan adalah kajian tentang situasi sosial dengan maksud untuk meningkatkan kualitas tindakan di dalamnya. Seluruh prosesnya (telaah, diagnosis, perencanaan, pelaksaanaan, pemantauan, dan pengaruh) menciptakan hubungan yang diperlukan antara eveluasi diri dan perkembangan profesional.

Penelitian tindakan kelas ini agar tercapai tujuan-tujuannya, maka dilaksanakan dengan proses pengkajian berdaur yang terdiri dari 4 tahap, sebagaimana ditunjukkan pada Gambar 1.

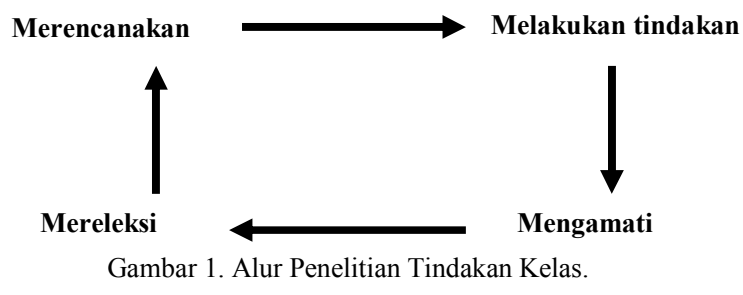

Setelah dilakukan refleksi yang mencakup analisis, sintesis, dan penilaian terhadap hasil pengamatan serta hasil tindakan yang telah dilakukan biasanya muncul permasalahan yang perlu mendapat perhatian sehingga pada gilirannya perlu dilakukan perencanaan ulang. Demikianlah tahap-tahap kegiatan ini terus berulang sampai sesuatu permasalahan dianggap teratasi. Proses penelitian tindakan dapat digambarkan sebagai berikut:

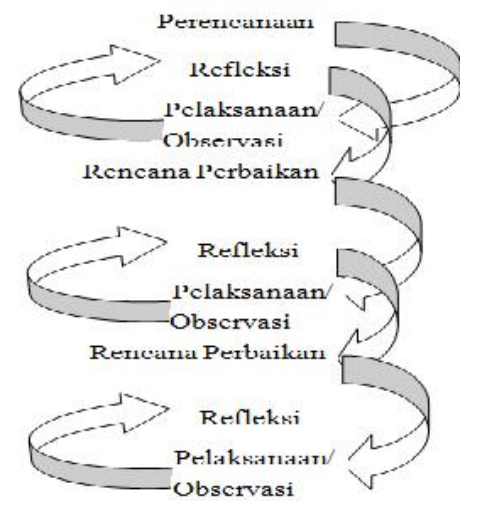

Gambar 2. Siklus Penelitian Tindakan Kelas.

HASIL DAN PEMBAHASAN

Penelitian ini diawali dengan observasi dan setelah mengetahui melakukan observasi awal. Lembar permasalahan yang berkaitan dengan proses 
belajar mengajar yang menuntut keaktifan mahasiswa. Maka pendekatan yang digunakan adalah pendekatan konstruktivistik melalui metode learning cycle yang dikombinasi dengan metode diskusi dan praktikum. Proses belajar mengajar ini memanfaatkan alat-alat laboratoruim. Pembelajaran yang dilakukan dalam penelitian ini melibatkan aktivitas mahasiswa, daya pikir kritis, keterampilan, dan kemandirian mahasiswa.

Proses pengumpulan dan penggalian data dalam penelitian ini dilakukan dengan menyelenggarakan beberapa proses belajar mengajar. Hal ini dilakukan dengan harapan tindakan, mencapai hasil yang maksimal. Berdasarkan observasi yang telah dilakukan maka pembelajaran menggunakan metode learning cycle, menggunakan instrumen yang telah disusun oleh peneliti. Instrumen yang digunakan sebagai perangkat pembelajaran terdiri dari Satuan Acara Perkuliahan (SAP), Lembar Kegiatan Mahasiswa (LKM), lembar soal dan penyelesaian, lembar evaluasi yang berupa pretest, posttest, lembar observasi, serta angket.

Perangkat pembelajaran sebelumnya telah dikonsultasikan dengan pakar sehingga sudah layak untuk pengambilan data. Pembelajaran yang dilaksanakan berpedoman pada SAP yang telah tersusun. Dalam SAP terdapat rambu-rambu yang akan dilaksanakan oleh peneliti dalam proses belajar mengajar yang akan dilaksanakan sesuai dengan rencana. Proses belajar mengajar dilaksanakan dengan cara membagi mahasiswa dalam tujuh kelompok dengan setiap kelompoknya rata-rata terdiri dari lima orang siswa secara acak. Pengelompokkan ini terjadi karena jumlah peralatan praktikum terbatas sehingga tidak bisa semua mahasiswa mendapatkan alat satu-satu. LKM yang digunakan disusun sedemikian rupa sehingga menuntut mahasiswa untuk menemukan konsep maupun masalah yang berkaitan dengan materi yang mahasiswa pelajari. Selain itu LKM benar-benar menuntut mahasiswa untuk menggambar desain percobaannya sendiri. LKM yang digunakan pada tiap siklus merupakan perbaikan dari LKM siklus sebelumnya.

Lembar soal dan penyelesaian merupakan lembar yang digunakan mahasiswa untuk membuat soal secara mandiri ataupun kelompok. Pada lembar ini juga mahasiswa menjawab soal yang mereka buat sendiri. Contoh lembar soal dan penyelesaian setiap siklusnya.

Penerapan metode learning cycle pada tiap siklusnya melalui beberapa siklus. Adapun rancangan dalam tiap siklus adalah sebagai berikut:

1. Siklus pertama, sub pokok bahasan pengamatan benda langit. Pada siklus ini aktivitas mahasiswa meliputi, tahap melibatkan (engage), yaitu dosen menumbuhkan minat dan rasa ingin tahu siswa terhadap materi yang akan dipelajari dengan cara dosen memberikan soal pretest, menyampaikan Standar Kompetensi (SK), Kompetensi Dasar (KD), dan indikator materi yang akan dipelajari dan memberikan apersepsi, sedangkan mahasiswa memberi contoh pengukuran suhu dalam kegiatan sehari-hari, dan guru memberikan permasalahan ke mahasiswa. Tahap mengungkapkan (explore), mahasiswa diberi kesempatan untuk memecahkan permasalahan yaitu dengan melakukan praktikum, dan pengambilan data. Data tersebut digunakan untuk menjawab permasalahan yang dihadapi yaitu pertanyaan dan tugas yang ada di LKM. Dalam praktikum mahasiswa diberi kesempatan untuk mendesain percobaan. Tahap menjelaskan (explain), yaitu mahasiswa melakukan diskusi di dalam kelompok dan diskusi kelas. Tahap mengembangkan (extend), mahasiswa secara berkelompok membuat soal dengan mengembangkan hasil diskusi, dan mengerjakan posttest. Tahap evaluasi (evaluate), merupakan evaluasi proses pembelajaran yang diperoleh dari hasil pekerjaan mahasiswa dari LKM, lembar soal dan penyelesaiannya serta pretest dan posttest. Selain dari hasil pekerjaan mahasiswa, angket yang diisi oleh mahasiswa juga menjadi bahan pertimbangan untuk evaluasi proses pembelajaran. 
JPFK, Volume 1, Nomor 1, Maret 2015 : 35 - 53

2. Siklus kedua, dengan sub pokok bahasan Penentuan Bintang Mati dan Hidup. Siklus ini dikembangkan dengan refleksi siklus pertama hanya saja aktivitas mahasiswa pada tahap mengungkapkan (explore) setiap mahasiswa sebelum melakukan praktikum memunculkan masalah atau membuat soal serta penyelesaiannya sesuai dengan konsep yang mereka miliki, berdasarkan dari tujuan percobaan. Pada tahap ini siswa juga melakukan praktikum, sehingga memperoleh data hasil percobaan. Dengan memanfaatkan data hasil percobaan yang ada, mahasiswa mengaitkannya dengan permasalahan atau soal yang mereka hadapi, sehingga mahasiswa mendapatkan kebenaran jawabannya. Mahasiswa juga memunculkan permasalahan atau soal yang baru berdasarkan data hasil percobaan. Pada tahap menjelaskan (explain), mahasiswa melakukan diskusi kelas, sehingga mahasiswa dapat menjawab (memperoleh kebenaran jawaban) masalah yang ada atau pertanyaan-pertanyaan yang muncul pada tahap sebelumnya dan memahami materi yang sedang dipelajari. Pada tahap mengembangkan (extend) siswa melengkapi pernyataan yang dibuat oleh dosen.

3. Siklus ketiga, dikembangkan dengan refleksi siklus kedua, materi adalah tentang sub pokok bahasan penentuan magnitude visual aktivitas mahasiswa pada tahap mengungkapkan (explore), jumlah soal tidak dibatasi, tetapi tidak menyimpang dari topik yang telah ditentukan dan pada tahap menjelaskan (explain) dalam mengerjakan soal dan diskusi kelompok siswa menggunakan hand out (ringkasan materi).

Untuk mendapatkan gambaran hasil penelitian yang telah dilaksanakan, maka disajikan deskripsi data dari proses awal sampai diperoleh data sebagai berikut:

1. Tindakan Siklus I

Sebelum melaksanakan tindakan pada siklus I, peneliti memberitahukan pada mahasiswa bahwa proses belajar mengajar astrofisika yang akan datang dilaksanakan pada pertemuan berikutnya adalah praktikum di observasi di luar.

Kegiatan selanjutnya peneliti membagi siswa dalam kelompok-kelompok kecil yang terdiri dari lima orang secara acak. Kegiatan selanjutnya peneliti menginformasikan materi yang akan dilaksanakan.

Proses belajar mengajar pada tindakan siklus I ini dipandu peneliti yang berperan sebagai dosen dengan mengambil pokok bahasan yang diajarkan. Proses belajar mengajar dimulai setelah semua mahasiswa menempatkan diri pada masing-masing kelompoknya, kemudian guru membuka dengan salam, dilanjutkan berdoa, dan melakukan presensi siswa.

a. Tahap-tahap Learning Cycle Siklus I

1) Tahap melibatkan (engange)

Pada tahap melibatkan (engange) ini, dosen merangsang pengetahuan awal mahasiswa tentang materi dan menumbuhkan minat dan rasa ingin tahu terhadap materi. Kegiatan untuk tahap ini diawali dengan guru membagi pretest. Pretest ini berfungsi untuk memberikan gambaran awal tentang materi yang akan dipelajari dan merangsang mahasiswa untuk belajar lebih lanjut. Setelah selesai mengerjakan pretest siswa mengumpulkan pekerjaannya kepada dosen. Kegiatan berikutnya dosen menyampaikan Standar Kompetensi (SK), Kompetensi Dasar (KD) dan indikator untuk materi, dilanjutkan dengan apersepsi, yaitu tentang pengamatan benda langit. dosen memberikan contoh yang berkaitan dengan materi. Kemudian dosen memberikan pertanyaan ke mahasiswa, untuk menyebutkan contoh dalam kehidupan sehari-hari, beberapa mahasiswa menjawab. dosen melanjutkan dengan memberikan permasalahan ke mahasiswa.

2) Tahap mengungkapkan (explore)

Untuk mengetahui kebenaran jawaban mahasiswa, dan mengetahui jawaban yang benar siswa melakukan praktikum. dosen menyuruh mahasiswa untuk mengambil alat-alat percobaan dan LKM yang telah disediakan. Setiap mahasiswa mendapatkan satu LKM. Setelah semua siswa menerima alat-alat percobaan dan LKM, siswa disuruh memahami LKM dan mengerjakan langkah kerja yang pertama, yaitu mengambar desain percobaan. Pada saat membuat desain percobaan ini, tampak sekali siswa 
kebingungan, banyak siswa yang bertanya pada dosen. Hal ini terjadi karena mahasiswa tidak terbiasa untuk mendesain percobaan, selama ini mereka terbiasa untuk langsung melaksanakan langkahlangkah percobaan yang siap saji. Bagi mahasiswa yang telah selesai mendesain percobaan, dosen menyuruh mereka untuk langsung melakukan langkah-langkah selanjutnya, yaitu memulai percobaan.

Selama proses praktikum (data diperoleh sebelumnya), ada beberapa mahasiswa yang bertanya kepada dosen tentang keterangan-keterangan yang belum jelas dalam percobaan. dosen juga mengontrol percobaan dari tiap kelompok, secara keseluruhan semua data percobaan yang siswa peroleh sesuai dengan konsep. Pada praktikum ini, percobaan hanya dilakukan oleh beberapa orang, sedangkan anggota kelompok yang lain hanya melihat temannya berpratikum. Jadi sebaran aktivitas berkisar antara $37,03 \%$ dan $92,59 \%$. Dari data tersebut dapat diungkapkan rata-rata aktivitas mahasiswa selama praktikum sebesar 59,92\%.

Selesai melakukan praktikum, siswa mencatat data hasil praktikum dan mengisikan pada LKM yang telah disediakan. Selesai mengisi tabel, dosen menyuruh siswa untuk mengisi tugas dari LKM. Kebanyakan mahasiswa tidak menggunakan buku referensi, sehingga dalam menyelesaikan tugas masih banyak mahasiswa yang bertanya-tanya dan bekerja sama dengan teman yang lainnya.

3) Tahap menjelaskan (explain)

Pada tahap menjelaskan (explain), mahasiswa melakukan diskusi klasikal, dimana mahasiswa menghubungkan pemahaman baru dengan pengetahuan awal mereka. Diskusi klasikal dilakukan setelah mahasiswa selesai menyelesaikan tugas LKM. Dalam diskusi mahasiswa diajak untuk membahas tentang pertanyaan dosen sebelum praktikum dengan mengaitkan data hasil praktikum yang telah dilakukan, serta tugas-tugas LKM. dosen menyuruh setiap kelompok untuk mempresentasikan hasil praktikumnya dan kelompok lain yang menanggapinya. Selama proses diskusi hanya beberapa mahasiswa yang aktif, itu pun karena ditunjuk oleh dosen. Setelah selesai diskusi hasil praktikum dilanjutkan dengan diskusi LKM. Tampak siswa masih terlihat pasif, mereka tidak langsung mengungkapakan jawaban LKM. Akhirnya dosen menunjuk mahasiswa untuk mengerjakaan tugas-tugas dari LKM di depan kelas dengan menuliskan jawabannya di papan tulis, namun mahasiswa masih belum ada yang mau maju ke depan kelas, mereka merasa takut kalau hasil pekerjaannya salah, mahasiswa masih merasa belum merasa bebas. Akhirnya dosen menyuruh perwakilan kelompoknya untuk maju ke depan dan menuliskan pekerjaan tugasnya dari LKM di papan tulis. Dosen yang menentukan nomor soal untuk setiap kelompoknya. Jawaban yang ditulis di papan tulis, dicocokkan bersamasama. Pada proses diskusi, dosen bertindak sebagai fasilitator, dosen berperan mengevaluasi dan meluruskan pemahaman mahasiswa. Dari rekaman diskusi ini dapat terungkap bahwa selama diskusi klasikal ini ada 9 orang mahasiswa yang memberikan pendapat dan 5 orang mahasiswa yang bertanya.

Setelah selesai diskusi, dosen membimbing mahasiswa untuk membuat kesimpulan dari hasil kegiatannya yang mengarah pada konsep fisisnya dan menyuruh siswa untuk mencatatnya. Kegiatan belajar mengajar dilanjutkan dengan dosen memberikan penegasan atau penguatan tentang konsep-konsep yang telah didapatkan dari proses diskusi dan dosen merangkumnya di papan tulis dan mahasiswa mencatat.

4) Tahap mengembangkan (extend)

Tahap mengembangkan (extend), tahap mahasiswa mengembangkan pemahaman yang telah dimiliki dengan menerapkan pemahamannya. Karena sudah tidak ada pertanyaan dari mahasiswa, dosen menyuruh setiap kelompok untuk membuat soal beserta penyelesainnya sesuai dengan pemahaman (konsep) yang telah didapatnya. Ternyata mahasiswa kebingungan merumuskan soal, karena selama ini mereka tidak pernah membuat soal beserta penyelesainnya sendiri, mahasiswa terbiasa menjawab soal yang 
diberikan oleh dosen. Selama membuat soal dan penyelesainnya, setiap anggota kelompok bekerja sama, mereka bersamasama berdiskusi dalam membuat soal dan penyelesaiannya, namun selama proses tersebut hanya beberapa mahasiswa saja yang aktif terlibat di dalamnya. Dalam satu kelompok ada anggota kelompok lain yang hanya melihat dan diam saja. Setiap kelompok membuat soal beserta penyelesaiannya pada lembar yang berbeda. Dari rekaman analisis membuat soal dan penyelesainnya terdapat 21 mahasiswa yang terlibat dalam membuat soal dan 23 mahasiswa yang terlibat dalam penyelesainnya.

Selesai membuat soal beserta jawabannya, guru menyuruh supaya lembar soal yang telah dibuat untuk ditukar dengan kelompok lain. Setelah setiap kelompok menerima soal dari kelompok lain, dosen menyuruh untuk menyelesaikan soal yang diterima dari kelompok lain, pada lembar kertas yang sama. Ketika penyelesaian soal hanya dilakukan oleh beberapa mahasiswa, sedangkan anggota kelompok yang lain hanya melihat dan diam. Selesai meyelesaikan soal, dosen menyuruh mahasiswa untuk mengembalikan lembar soal yang telah diselesaikan kepada kelompok asal yang membuat soal. Setelah soal kembali, dosen menyuruh setiap kelompok untuk mencocokkan hasil pekerjaan kelompok lain, dengan jawaban yang telah mereka buat. Selesai dicocokkkan lembar tersebut diberikan kepada kelompok yang menyelesaikaannya, dengan tujuan supaya mengetahui letak kesalahannya. Jika masih ada yang salah dosen menyuruh perwakilan kelompok yang membuat soal untuk menjawab jawaban yang benar di papan tulis, sesuai dengan kunci yang dibuatnya, pada tahap ini dosen mengevaluasi dan meluruskan jawaban mahasiswa jika masih salah. Ratarata jawaban mahasiswa adalah benar.

Setelah setiap kelompok mengetahui hasil pekerjaannya, dan tidak ada pertanyaan dari mahasiswa, dosen membagikan soal posttest untuk mengetahui tingkat penguasaan konsep mahasiswa dan mengembangkan konsep yang dimilikinya untuk diterapkan pada situasi yang berbeda.

5) Tahap evaluasi (evaluate)

Hasil pretest, jawaban LKM, soal dan penyelesaian mahasiswa serta posttest mahasiswa, menjadi bahan evaluasi proses pembelajaran. Selain dari hasil pekerjaan mahasiswa, jawaban angket oleh mahasiswa juga menjadi bahan pertimbangan untuk proses pembelajaran.

a) LKM I

Bagian-bagian LKM ini terdiri dari Standar Kompetensi, Kompetensi Dasar, indikator, alat dan bahan, langkah kerja, tabel percobaan, dan tugas, serta kesimpulan. Pada LKM I terdapat 3 kegiatan percobaan yang harus dilakukan siswa untuk menemukan konsep mengenai pengamatan benda langit.

Pada LKM ini tidak disediakan gambar desain percobaan yang akan dilakukan, tetapi desain diserahkan kepada mahasiswa. Pada tahap ini tampak mahasiswa kebingungan, karena selama ini mahasiswa terbiasa dilayani, tapi setelah dijelaskan akhirnya berjalan dengan lancar, meskipun memakan waktu yang lama. Untuk langkah percobaan selanjutnya berjalan dengan baik.

Kekurangan yang terdapat pada LKM I ini adalah langkah percobaan yang menyuruh mahasiswa untuk menggambar desain percobaan, mahasiswa tidak mempunyai acuan bila tidak dijelaskan oleh dosen, sehingga pada langkah ini memakan waktu yang lama. Seharusnya mahasiswa mengacu pada langkah percobaan selanjutnya. Dengan demikian mahasiswa mempunyai arahan untuk mendesain percobaan, yaitu dengan mendiskripsikan kalimat-kalimat dalam langkah-langkah percobaan ke dalam desain gambar. Dalam LKM I, setiap percobaan tidak ada tujuan percobaan. Nilai LKM untuk siklus I ratarata nilai $\mathrm{LKM}$ adalah 7,51. Berdasarkan data tersebut rata-rata persentase jawaban LKM untuk siklus I yang benar $76,29 \%$ dan yang salah $23,71 \%$

b) Lembar Soal dan Penyelesainnya

Lembar soal dan penyelesainnya merupakan lembar kertas yang digunakan oleh mahasiswa untuk membuat dan 
menyelesaikan soal. Pada siklus I ini dalam membuat dan menyelesaikan soal dilakukan secara berkelompok. Pada awalnya dosen menyuruh setiap kelompok untuk menemukan masalah dan merumuskannya dalam bentuk soal berdasarkan konsep yang telah mereka peroleh selama belajar mengajar sebelumnya, namun mahasiswa kebingungan tentang soal apa yang akan dibuat. Hal ini disebabkan mahasiswa tidak terbiasa membuat soal, biasanya mahasiswa tinggal mengerjakan soal yang telah dibuat oleh dosen. Akhirnya dosen memutuskan untuk menyuruh mahasiswa membuat soal tentang pengamatan benda langit. Selesai membuat soal, maka soal tersebut mereka selesaikan pada lembar kertas yang berbeda. Berdasarkan data tersebut soal yang sesuai $84,6 \%$ dan soal yang tidak sesuai $15,4 \%$ dan jawaban yang sesuai dengan konsep $82,9 \%$ dan yang tidak sesuai dengan konsep 17,1\%.

c) Pretest dan posttest

Salah satu untuk mementukan indikator keberhasilan produk pembelajaran yaitu melalui hasil evaluasi mahasiswa dari pretest dan posttest. Hasil evaluasi mahasiswa ini mencerminkan penguasaan konsep fisika. Pada siklus I materi astrofisika yang disajikan jumlahnya masih relatif sedikit.

Tabel 1. Hasil Rekaman pretest dan posttest Siklus I

\begin{tabular}{cccc}
\multicolumn{3}{c}{ Tabel 1. Hasil Rekaman pretest dan posttest } & Siklus I \\
\hline Pretest & Posttest & $\begin{array}{c}\text { Kenaikan } \\
\text { pretest ke } \\
\text { posttest }\end{array}$ \\
\hline Rata-rata & 6,79 & $\mathbf{8 , 5 0}$ & 1,71 \\
\hline $\begin{array}{c}\text { Nilai lebih } \\
\text { dari 6 }\end{array}$ & $\mathbf{6 8 , 4 0 \%}$ & $\mathbf{9 7 , 4 0 \%}$ & $\mathbf{2 9} \%$ \\
\hline
\end{tabular}

Lembar rekaman pretest dan posttest siklus I ini terdapat pada Lampiran 6. Skor nilai yang dicapai mahasiswa berkisar antara 5 dan 10, dengan kenaikan nilai ratarat pretest ke nilai rata-rata posttest sebesar 1,71. Jumlah mahasiswa yang mendapatkan nilai 6 atau lebih, dari kegiatan pretest ke posttest mengalami kenaikan sebanyak $29 \%$.

d) Angket

Setelah mengerjakan posttest, mahasiswa mengisi angket mengenai proses belajar mengajar yang telah mereka ikuti. Angket tersebut mengevaluasi tentang semua perangkat pembelajaran dan kegiatan yang mahasiswa lakukan. Berdasarkan hasil distribusi jawaban angket yang diperoleh menunjukkan bahwa $8(20,51 \%)$ mahasiswa senang sekali, $22 \quad(56,41 \%)$ mahasiswa senang, 7 (17,95\%) mahasiswa kurang senang dan $2(5,13 \%)$ mahasiswa tidak senang mengikuti proses belajar mengajar selama siklus I. Berdasarkan angket itu pula mahasiswa menyarankan agar proses belajar mengajar berikutnya supaya alat-alat percobaan disediakan, dan soal pretest dan posttest ditambah. Selama proses belajar mengajar juga teramati beberapa kejadian yang tercatat dalam jurnal harian. Berdasarkan wawancara dan diskusi serta hasil lembar pengamatan oleh observer, menunujukkan bahwa proses belajar mengajar astrofisika menggunakan praktikum sangat membantu mahasiswa dalam mempelajari astrofisika. Oleh karena itu dosen menyetujui seandainya praktikum digunakan pada proses belajar mengajar untuk pokok bahasan lain. Saran dari observer adalah agar format LKM langkah pertama diperbaiki sehingga mahasiswa lebih mudah memahaminya, selain itu juga dosen menjelaskan langkah-langkah percobaan yang akan dilakukan agar makin jelas.

b. Refleksi Siklus I

Adapun hasil refleksi pada tindakan siklus I adalah:

1) Kekurangan siklus I

a) Dosen tidak menjelaskan bagianbagian LKM, terutama langkahlangkah percobaan sehingga mahasiswa kebingungan dalam menggambar desain percobaan.

b) Setiap percobaan tidak dicantumkam tujuan percobaan.

c) Kerjasama antarmahasiswa dalam praktikum masih kurang, sehingga praktikum hanya didominasi oleh beberapa mahasiswa.

d) Mahasiswa kesulitan untuk merumuskan masalah/pertanyaan soal, sebab selama ini mahasiswa terbiasa menunggu sajian materi dosen.

e) Peran mahasiswa dalam diskusi masih kurang, mahasiswa masih 
perlu ditunjuk untuk dapat mengungkapkan pendapatnya.

f) Dosen kurang tegas sehingga masih banyak mahasiswa yang bekerja sama dalam mengerjakan pretest dan posttest.

2) Rencana Perbaikan

a) Dosen menjelaskan langkah-langkah percobaan, selain itu juga dengan cara memperjelas kalimat langkah pecobaan nomor 1, yaitu agar dalam menggambar desain percobaan, mahasiswa mengacu pada langkahlangkah percobaan 2 sampai selesai.

b) Mencantumkan tujuan percobaan setiap percobaan.

c) Dosen memotivasi mahasiswa untuk bekerjasama dalam mengerjakan praktikum.

d) Dosen menjelaskan bagian-bagian LKM terutama tujuan percobaan, agar mahasiswa mempunyai arahan dalam membuat soal.

e) Dosen memberikan bonus nilai dan pujian bagi mahasiswa yang berani mengungkapkan pendapatnya.

f) Dosen tegas dalam menghadapi mahasiswa, agar mahasiswa melaksanakan pekerjaannya secara mandiri.

g) Berdasarkan hasil diskusi dengan pengamat bahwa dalam membuat soal dan penyelesaiannya dilakukan oleh setiap mahasiswa, dengan harapan semua mahasiswa faham dengan konsep fisikanya.

2. Tindakan Siklus II

Pelasanaan siklus II didasarkan pada refleksi siklus I. Pada siklus II ini mengalami perbaikan tindakan yaitu meliputi cara pelaksanaan proses belajar mengajar serta LKM yang digunakan dalam praktikum. Materi yang disajikan dalam siklus II yaitu tentang sub pokok konsep penentuan bintang hidup dan bintang mati.

Proses belajar mengajar dimulai setelah semua mahasiswa menempatkan diri pada kelompoknya masing-masing. Kemudian dosen membuka dengan salam, selanjutnya dosen memimpin doa. Untuk selanjutnya dosen melakukan presensi siswa. Semua mahasiswa masuk, tidak ada yang absen. a. Tahap-tahap Learning Cycle Siklus II

1) Tahap melibatkan (engange)

Tahap ini diawali dengan dosen memberikan pretest. Pretest berfungsi untuk memberikan gambaran awal tentang materi yang akan dipelajari dan mengetahui kemampuan awal mahasiswa terhadap materi yang akan dipelajari dan merangsang mahasiswa untuk belajar lebih jauh lagi tentang materi yang akan dipelajari. Setelah semua mahasiswa selesai mengerjakan pretest, mahasiswa mengumpulkan pekerjaannya pada dosen. Kegitan proses belajar mengajar selanjutnya, guru memberikan penjelasan SK, KD dan indikator untuk pelajaran yang akan dipelajari, dan dilanjutkan dengan pengarahan dan gambaran tentang proses belajar mengajar yang akan dilakukan. Proses belajar mengajar dilanjutkan dengan dosen memberikan apersepsi pada siswa yaitu dengan mengaitkan pembelajaran sebelumnya dan memberikan contoh dalam kehidupan sehari-hari. Misalnya, saat menyetrika kita akan merasa panas.

2) Tahap mengungkapkan (explore)

Pada tahap mengungkapkan (explore) terdapat aktivitas mahasiswa untuk memecahkan persolannya sendiri. dosen menyuruh mahasiswa untuk mengambil alat-alat percobaan dan LKM yang telah disediakan. Setelah semua mahasiswa mendapatkan LKM, dosen menyuruh mahasiswa untuk membaca dan mencermati LKM. Sebelum melakukan setiap percobaan dosen menyuruh mahasiswa untuk membuat rumusan masalah (soal) berdasarkan tujuan setiap percobaannya, minimal satu soal. Mahasiswa juga mencoba menjawab soal sesuai kemampuannya. Setelah itu mahasiswa langsung melakukan langkah kerja pertama, yaitu mendesain percobaan. Pada saat mendesain percobaan ini mahasiswa sudah mulai lancar, mahasiswa langsung mengacu pada langkah percobaan kedua sampai selesai. Tanpa petunjuk dari dosen, mahasiswa langsung melakukan praktikum.

Selama praktikum, mahasiswa sudah terbiasa dengan kegiatan praktikum, dan mahasiswa tidak banyak bertanya dosen. Dosen memberikan arahan jika diperlukan. 
Selain itu terlihat kerja sama antar mahasiswa dalam kelompok mengalami peningkatan. Hal ini terlihat dari distribusi kerja mahasiswa yang dilakukan selama praktikum yaitu berkisar antara $43,30 \%$ dan $85,00 \%$. Dari rekaman tersebut pula dapat diungkapkan pula bahwa rata-rata aktivitas mahasiswa selama praktikum $67,90 \%$

Setelah setiap percobaan selesai, mahasiswa melakukan analisis dalam diskusi kelompok. Kemudian mahasiswa mencocokkan jawaban dari soal yang dibuat sebelum mereka melakukan percobaan. Para mahasiswa berdiskusi di kelompoknya sendiri dan memecahkan permasalahan bersama. Dengan demikian mahasiswa tahu kebenaran dari jawabannya.

Setelah itu dosen menyuruh mahasiswa untuk membuat soal beserta penyelesaiannya, minimal satu berdasarkan informasi (konsep) yang mereka dapatkan selama praktikum dan diskusi kelompok. Variasi soal yang dibuat tidak banyak, karena antarmahasiswa dalam satu kelompok masih bekerja sama dengan teman yang lain dalam satu kelompok, sehingga rata-rata dalam satu kelompok hampir sama.

3) Tahap menjelaskan (explain)

Untuk menyamakan pemahaman antarmahasiswa dalam kelas, maka diadakan diskusi klasikal. Setiap kelompok diberi kesempatan untuk melakukan presentasi, yaitu dengan cara perwakilan kelompoknya menyampaikan hasil dan kesimpulan praktikumnya. Selain itu juga setiap kelompok menyampaikan permasalahan (soal) yang dibuatnya beserta penyelesaiannya. Kelompok lain menanggapi dan mengkritisi dari setiap kelompok yang presentasi. Mahasiswa lain berkesempatan untuk menanyakan kepada kelompok penyaji apabila tidak ada yang jelas dari paparan mereka. Untuk menumbuhkan keberanian mengungkapkan pendapatnya, dosen memberikan skor atau nilai tambah bagi mahasiswa yang berani berpendapat dan pujian. Beberapa siswa mengikuti jalannya diskusi, namun masih ada juga mahasiswa yang ramai sendiri tidak memperhatikan, sehingga kadang- kadang dosen memberikan pertanyaan ke mahasiswa tersebut atau disuruh untuk mengulang penjelasan dari presentasi kelompok sebelumnya. Sebagai fasilitator, dosen berperan untuk mengevaluasi dan meluruskan pemahaman mahasiswa atau memberikan jawaban alternatif. Setelah semua kelompok mempresentasikan hasil praktikumnya, dosen mengarahkan siswa untuk menyimpulkan hasil diskusi yang mengarah pada konsep fisis, yaitu dengan cara memancing mahasiswa dengan pertanyaan-pertanyaan yang mengarah ke konsep fisisnya dan mahasiswa yang menjawabnya. Kegiatan selanjutnya, mahasiswa membuat kesimpulan berdasarkan hasil diskusi. Dari rekaman diskusi ini dapat terungkap bahwa selama diskusi klasikal ini, ada 9 orang siswa yang bertanya dan 13 siswa yang mengungkapkan jawabannya.

4) Tahap mengembangkan (extend)

Pada tahap mengembangkan (extend), siswa mengembangkan dan menerapkan pengetahuan yang telah mereka miliki pada situasi yang berbeda. Proses belajar mengajar selanjutnya yaitu mahasiswa melengkapi pernyataan yang belum lengkap, yang mengacu dari setiap percobaannya. Setelah semua mahasiswa selesai mengerjakan tugas, mahasiswa kemudian mengumpulkan hasil pekerjaan tugasnya kepada dosen. Kemudian dosen bertanya kepada mahasiswa, apa ada kesulitan. Beberapa mahasiswa menjawab ada. Untuk membahas soal yang tidak bisa dikerjakan, maka diadakan diskusi klasikal kembali, yaitu dengan cara dosen bertanya kesulitan pada masalah apa, dan menyuruh mahasiswa yang bisa menjawab untuk menjelaskan kepada teman yang lainnya. dosen mengevaluasi dan meluruskan jawaban mahasiswa.

Setelah tidak ada pertanyaan lagi, dosen membagikan soal posttest untuk mengetahui tingkat penguasaan konsep mahasiswa. Mahasiswa yang mengerjakan posttest sebanyak 37 mahasiswa, ada 2 mahasiswa yang tidak mengerjakan posttest sebab tidak masuk. Secara lengkap soal posttest pada siklus II terdapat pada Lampiran 12. Dalam pelaksanaan evaluasi 
ini, dosen tidak lupa untuk menegaskan bahwa soal dikerjakan mandiri.

Selain mengerjakan soal evaluasi, mahasiswa juga mengisi angket mengenai proses belajar mengajar yang telah dilakukan. Angket tersebut mengevaluasi tentang semua perangkat pembelajaran dan kegiatan yang mahasiswa lakukan. Berdasarkan distribusi jawaban angket yang diperoleh menunjukkan bahwa $11(29,73 \%)$ mahasiswa senang sekali, $22 \quad(59,46 \%)$ mahasiswa yang senang, $4 \quad(10,81 \%)$ mahasiswa yang kurang senang dan tidak ada mahasiswa yang tidak senang mengikuti proses belajar mengajar selama siklus II.

5) Tahap evaluasi (evaluate)

Hasil pretest, jawaban LKM, soal dan penyelesaian mahasiswa, tugas posttest mahasiswa, menjadi bahan evaluasi proses pembelajaran. Selain dari hasil pekerjaan mahasiswa, jawaban angket oleh mahasiswa juga menjadi bahan pertimbangan untuk proses pembelajaran.

a) LKM II

LKM II merupakan penyempurnaan dari LKM I. Dalam LKM II ada perubahan format dari langkah percobaan nomor satu, tujuan setiap percobaan dicantumkan dan tidak ada tugas, dengan tujuan mahasiswa sendiri yang merumuskan permasalahannya. Di dalam LKM II terdapat 3 kegiatan percobaan yang harus dilakukan untuk menemukan konsep mengenai penetuan bintang mati dan bintang hidup .

Tujuan percobaan LKM II merupakan penjabaran dari indikator SAP II. Dari tujuan percobaan, mahasiswa diharapkan dapat menemukan sendiri masalah yang harus diselesaikan. Alat-alat percobaan yang digunakan dalam tiap percobaan pada LKM II telah tersedia di laboratorium. Langkah-langkah percobaan pada LKM II ini hampir sama dengan LKM I, hanya saja ada perbaikan pada langkah kerja I.

LKM II terdiri dari empat percobaan. Percobaan I untuk menemukan pengamatan benda langit. Percobaan II untuk menentukan hubungan antara kalor dengan perubahan suhu padabintang mati dan bintang hidup. Percobaan III untuk mencari intensitas dan luminusitas benda langit. Percobaan IV untuk mencari hubungan mgnitudo visual.

Pada semua percobaan hampir semua mahasiswa tidak mengalami kesulitan, praktikum berjalan lancar. Semua kelompok mendapatkan data sesuai dengan konsep yang ada.

Hasil pekerjaan mahasiswa dalam LKM digunakan sebagai indikator keberhasilan produk, sedangkan aktivitasaktivitas mahasiswa yang dilakukan selama praktikum merupakan indikator keberhasilan proses. Berdasarkan data tersebut rata-rata nilai LKM untuk siklus II 7,83 , sedangkan untuk rata-rata persentase jawaban LKM siklus II tersaji dalam Lampiran 10. Berdasarkan data tersebut rata-rata persentase jawaban LKM untuk siklus II yang benar $88,47 \%$ dan yang salah $11,53 \%$.

b) Lembar Soal dan Penyelesaiannya.

Pada siklus II, soal yang dibuat mahasiswa dikerjakan oleh mahasiswa sendiri. Setiap mahasiswa wajib membuat soal dengan jawabannya sesuai dengan konsep yang dimilikinya, dengan harapan semua mahasiswa bekerja dan tahu seberapa jauh konsep yang dimilikinya. Setiap mahasiswa membuat satu soal sebelum melakukan percobaan berdasarkan tujuan percobaan dan satu soal sesudah percobaan berdasarkan konsep dan pengetahuan yang dimilikinya. Variasi soal yang dibuat mahasiswa masih sedikit, sebab mahasiswa yang satu mencontek mahasiswa yang lain dalam satu kelompok. Dengan melakukan praktikum mahasiswa dapat menjawab permasalahan yang dihadapinya.

Berdasarkan data tersebut rata-rata pertanyaan/soal yang sesuai sebesar $58,66 \%$ dan yang tidak sesuai $41,34 \%$ dan untuk jawaban yang sesuai $58,34 \%$ dan yang tidak sesuai $41,66 \%$.

c) Tugas

Tugas yang dikerjakan oleh mahasiswa merupakan bagian dari tahap mengembangkan (extend). Tugas ini sebagai upaya untuk mengembangkan pemahaman yang telah dimiliki mahasiswa dengan menerapkannya pada situasi yang berbeda. Mahasiswa meyelesaikan tugas 
yang di dalamnya merupakan permasalahan yang dijumpai dalam kehidupan sehari-hari. Dari kegitan ini, mahasiswa diharapkan dapat menyimpulkan kembali apa yang telah mereka pelajari.

Berdasarkan data tersebut, mahasiswa yang menjawab benar semua untuk tugas I sebesar 46,2\%, untuk tugas II sebesar 59\%, untuk tugas III sebesar $100 \%$, dan untuk tugas IV sebesar 69,1\%. Berdasarkan data tersebut, nilai rata-rata tugas untuk siklus II 91,82 .

d) Pretest dan posttest

Pada siklus II materi fisika yang disajikan jumlahnya lebih banyak dibandingkan siklus I. Hasil evaluasi diberitahukan ke mahasiswa, sebagai umpan balik ke mahasiswa. Analisis hasil pretest dan post tes terdapat pada Tabel 2 di bawah ini.

Tabel 2. Hasil Rekaman pretest dan posttest Siklus II

\begin{tabular}{lccc}
\hline Pretest & Posttest & $\begin{array}{c}\text { Kenaikan } \\
\text { Pretest ke } \\
\text { Postest }\end{array}$ \\
\hline Rata-rata & 6,32 & 9,37 & 3,05 \\
\hline Nilai lebih dari 6 & $56,4 \%$ & $100 \%$ & $43,6 \%$ \\
\hline
\end{tabular}

Setelah dianalisis didapatkan data seperti pada tabel di atas. Skor pretest yang dicapai mahasiswa berkisar antara 2 dan 9 , dan untuk skor posttest berkisar antara 7 dan 10, dengan kenaikan nilai rata-rata pretest ke nilai rata-rata posttest sebesar 3,05 . Jumlah mahasiswa yang mendapatkan nilai 6 atau lebih, dari kegiatan pretest ke posttest mengalami kenaikan $43,6 \%$.

b. Refleksi

Adapun refleksi pada siklus II adalah:

1) Kekurangan siklus II

a) Dalam diskusi kelompok, mahasiswa tidak membawa buku paket maupun buku referensi yang lain, sehingga mahasiswa membutuhkan waktu yang lama untuk menemukan konsep fisisnya.

b) Variasi soal masih sedikit, dalam satu kelompok soal yang dibuat sama.

2) Rencana Perbaikan

a) Setiap kelompok diberi ringkasan materi, dengan demikian mahasiswa dapat memecahkan permasalahan yang dihadapinya dan mendapatkan konsep yang jelas dan mantap.

b) Setiap mahasiswa tidak dibatasi jumlah soal yang dibuat, asal tidak keluar dari materi yang dibahas.

3. Tindakan Siklus III

Pelaksanaan tindakan siklus III didasarkan pada refleksi siklus II. Pada kegiatan siklus II ini mengalami perbaikan tindakan yaitu meliputi cara pelaksanaan proses belajar mengajar. Materi yang disajikan dalam siklus ini adalah tentang sub pokok bahasan perubahan wujud. Dosen membuka proses belajar mengajar dengan salam, dilanjutkan dengan berdoa dan melakukan presensi mahasiswa. Ternyata ada mahasiswa yang tidak masuk sebanyak 2 mahasiswa, dikarenakan sakit dan izin.

a. Tahap-tahap Learning Cycle Siklus III

1) Tahap melibatkan (engange)

Kegiatan berikutnya, dosen membagikan pretest. Hal tersebut tetap dilakukan karena dapat memberikan gambaran yang jelas mengenai konsep yang akan ditemukan mahasiswa, selain itu juga untuk mengetahui kemampuan awal mahasiswa tentang konsep atau materi yang akan dipelajari dan merangsang siswa untuk belajar lebih jauh materi yang akan dipelajari. Tampak bahwa mahasiswa sudah terbiasa dengan kegiatan ini. Hal ini terlihat bahwa mahasiswa tanpa menunggu perintah dari dosen, mahasiswa langsung mengerjakan soal-soal yang ada pada lembar pretest. Pada tahap melibatkan (engange), mahasiswa mulai menumbuhkan minatnya terhadap materi yang akan dipelajari dan mahasiswa mengakses pengetahuan awal mereka. Tahap ini diawali dengan dosen menyampaikan SK, $\mathrm{KD}$, dan indikator untuk pelajaran yang akan dipelajari. Hal ini dilakukan supaya mahasiswa tahu apa tujuan dari kegitan belajar mengajar hari ini. Kegiatan selanjutnya, dosen memberikan pengantar, yaitu memancing ingatan mahasiswa mengenai materi yang telah didapatkan mahasiswa pada pelajaran sebelumnya. Dosen memberikan pertanyaan-pertanyaan 
ke mahasiswa untuk menyebutkan contoh perubahan benda yang dapat diamati secara visual dalam kehidupan sehari-hari. Tanggapan yang diberikan mahasiswa siswa cukup baik. Hal ini dibuktikan dengan banyaknya mahasiswa yang menjawab pada saat dosen mengemukakan pertanyaan. Jawaban disampaikan mahasiswa secara beramai-ramai.

2) Tahap mengungkapkan (explore)

Proses belajar mengajar selanjutnya, mahasiswa melakukan praktikum. Sebelumnya dosen menyuruh siswa untuk mengambil LKM dan alat-alat percobaan yang telah disiapkan. Setiap Maha sebelum melakukan diwajibkan untuk membuat soal berdasarkan tujuan dari percobaan yang akan dilakukan. Hal ini tetap dilakukan supaya mahasiswa mempunyai tujuan dengan praktikum yang akan dilakukannya. mahasiswa sendiri yang membuat soal/rumusan masalah dan mahasiswa juga yang menyelesaikannya. Jumlah soal yang dibuat tidak dibatasi, namum materinya dibatasi pada masalah magnitude visual. Tampak bahwa mahasiswa membuat soal lebih dari dua.

Setelah selesai membuat soal dan jawabannya, tanpa perintah dari dosen mahasiswa langsung membaca LKM yang ada di depannya, dan melakukan langkah percobaan yang pertama, yaitu mendesain percobaan, dan dilanjutkan dengan langkahlangkah berikutnya. Saat mahasiswa melakukan percobaan, dosen berkeliling dari kelompok satu ke kelompok yang lain untuk mengontrol kegiatan percobaan mahasiswa. Jika diperlukan dosen memberikan penjelasan ke mahasiswa. Selama kegiatan praktikum, mahasiswa bekerjasama dengan mahasiswa yang lainnya dalam satu kelompok. Setiap kelompok terfokus pada LKM dan kegiatan percobaannya, ini menunjukkan bahwa mahasiswa sudah terbiasa dengan kegitan praktikum. Hal ini terlihat dari distribusi kerja mahasiswa yang dilakukan selama praktikum yaitu berkisar dari 56,30\% sampai $87,50 \%$. Dari rekaman tersebut pula dapat diungkapkan pula bahwa rata-rata aktivitas mahasiswa selama praktikum $70,80 \%$.
Sebelum melakukan praktikum, dosen membagikan ringkasan materi, dimana setiap kelompok mendapatkan satu. Berdasarkan data hasil percobaan dan ringkasan materi, mahasiswa melakukan diskusi kelompok untuk menjawab pertanyaan yang belum terjawab pada tahap sebelumnya dan mendapatkan kebenaran jawabannya sesuai dengan pengetahuan yang dibentuknya dari praktikum dan informasi yang diperolehnya. Rata-rata data hasil percobaan setiap kelompok, belum sempurna mendekati konsep yang diharapkan. Dikarenakan dengan ringkasan materi yang telah diberikan membantu mahasiswa untuk menemukan konsep yang benar. Pada kegiatan ini yang membaca ringkasan materi hanya beberapa siswa saja. Mahasiswa yang lainnya hanya bertanya dengan teman. Aktivitas mahasiswa membuat soal, melakukan praktikum sampai memperoleh data.

3) Tahap menjelaskan (explain)

Untuk menyamakan dan membahas konsep hasil percobaan, kemudian dilaksanakan diskusi kelas. Ringkasan materi (hand out) menjadi pendamping diskusi. Pelaksanaan diskusi kelas didahului dengan presentasi hasil percobaan beberapa kelompok. Dosen memancing keaktifan mahasiswa dalam berpendapat dengan memberikan pertanyaan-pertanyaan mengenai hasil percobaanya dan bagi yang berani berpendapat mendapatkan nilai plus. Selain membahas hasil percobaan, juga membahas tentang soal-soal atau masalahmasalah yang telah mereka buat. Secara acak dosen menyuruh perwakilan kelompoknya untuk menyampaikan soal dan jawabannya dengan menuliskannya di papan tulis. Kelompok yang lain juga melakukan hal yang sama namun berbeda untuk soalnya, sehingga tidak ada yang sama. Setelah semua kelompok menuliskan soal dan jawabannya di papan tulis, kegiatan berikutnya yaitu membahas tentang soal dan jawaban tersebut, dengan cara mencocokkan jawaban tersebut, sesuai dengan konsep yang diperolehnya dari data hasil percobaan, ringkasan materi, dan diskusi. Setiap mahasiswa berhak untuk bertanya, jika belum jelas. Kelompok yang 
bersangkutan akan memberikan penjelaskan. Disini dosen bertindak sebagai fasilitator, yaitu berperan untuk mengevaluasi dan meluruskan pemahaman mahasiswa atau memberikan jawaban alternatif. Pada diskusi klasikal ini hampir semua mahasiswa berperan aktif. Hal ini terbukti dengan mahasiswa menjawab pertanyaan dari guru, meskipun mereka menjawabnya secara lisan dan beramairamai. Selain itu beberapa mahasiswa mengeluarkan pendapatnya secara bebas, tanpa dipaksa oleh dosen. Hal ini menunjukkan bahwa siswa sudah terbiasa dengan kegitan diskusi. Diskusi klasikal dilaksanakan sampai menghasilkan kesimpulan-kesimpulan yang berhubungan dengan konsep. Dari rekaman diskusi ini terungkap bahwa selama diskusi klasikal ini, ada 14 orang mahasiswa yang bertanya dan 15 orang mahasiswa mengemukakan pendapatnya.

Setelah diskusi selesai, dosen memberikan penegasan atau penguatan tentang konsep-konsep yang telah mahasiswa dapatkan dari proses diskusi yaitu dengan menuliskannya di papan tulis, dan mahasiswa mencatatnya.

4) Tahap mengembangkan (extend)

Karena tidak ada lagi pertanyaan dari mahasiswa, dosen membagikan tugas ke setiap kelompok yaitu soal yang berbentuk pernyataan yang belum lengkap. Tugas mahasiswa untuk melengkapi pernyataan tersebut, sehingga membentuk pernyataan yang benar. Pada kegiatan ini anggota kelompok bekerjasama untuk menyelesaikannya sesuai dengan konsep yang diperolehnya dari tahap sebelumnya.

Wakil dari kelompok mengumpulkan tugasnya jika sudah selesai kepada dosen. Selanjutnya guru bertanya ke siswa apakah ada yang sulit atau tidak bisa menjawab dari tugas tersebut. Kebanyakan mahasiswa menjawab yang tidak bisa yaitu tentang perhitungan. Mahasiswa berdiskusi klasikal kembali untuk membahas soal yang menjadi hambatan selama mengerjakan tugas. Dosen memberi kesempatan kepada siapa yang bisa menerangkannya, yaitu dengan menuliskannya di papan tulis dan dosen yang mengevaluasi serta meluruskan dari jawaban mahasiswa tersebut. Mahasiswa menyimpulkan kembali apa yang telah mahasiswa miliki. Berdasarkan data tersebut rata-rata nilai untuk siklus III sebesar 89,16.

Setelah tidak ada pertanyaan lagi, dosen membagikan soal posttest. Kegiatan posttest mengenai pemahaman mahasiswa terhadap konsep yang diperoleh tetap diadakan. Meskipun dosen sudah memberitahukan untuk mengerjakan soal posttest sendiri, akan tetapi masih ada mahasiswa yang berdiskusi dengan temannya. Hal ini dilakukan mahasiswa ketika mengalami kesulitan dalam mengerjakan soal-soal perhitungan. Jika dilihat dari frekuensi mahasiswa yang berdiskusi dalam mengerjakan soal posttest, maka jumlah mahasiswa yang melakukan diskusi siklus III paling kecil.

5) Tahap evaluasi (evaluate)

Hasil pretest, jawaban LKM, soal dan penyelesaian mahasiswa, tugas serta posttest mahasiswa, menjadi bahan evaluasi proses pembelajaran. Selain dari hasil pekerjaan mahasiswa, jawaban angket oleh mahasiswa juga menjadi bahan pertimbangan evaluasi untuk proses pembelajaran.

a) LKM III

Format LKM III sama dengan format LKM II. Di dalam LKM III terdapat 1 kegiatan percobaan yang harus dilakukan untuk menemukan konsep mengenai penentuan magnitude visual.

Tujuan percobaan LKM III merupakan penjabaran dari indikator SAP III. Dari tujuan percobaan, mahasiswa diharapkan dapat menemukan sendiri masalah yang harus didelesaikan. Alat-alat percobaan yang digunakan dalam tiap percobaan pada LKM III telah tersedia di laboratorium. LKM III terdiri dari satu percobaan.

Berdasarkan data tersebut rata-rata nilai LKM untuk siklus III 7,30. Berdasarkan data tersebut rata-rata persentase jawaban LKM untuk siklus III yang benar 75,40\% dan yang salah $24,60 \%$.

b) Lembar Soal dan Penyelesaiannya

Pada siklus III, soal yang dibuat mahasiswa dikerjakan oleh mahasiswa sendiri. Setiap mahasiswa wajib membuat 
soal dengan jawabannya sesuai dengan pengetahuan yang dimilikinya, dengan harapan semua mahasiswa bekerja dan tahu seberapa jauh pengetahuan yang dimilikinya. Setiap mahasiswa membuat soal sebelum melakukan percobaan berdasarkan tujuan percobaan berdasarkan konsep yang dimilikinya. Variasi soal yang dibuat mahasiswa meningkat dari sebelumnya, sebab setiap mahasiswa membuat soal lebih dari satu dan dikerjakan sendiri, meskipun masih ada mahasiswa yang mencontek. Siklus III pada tahap membuat soal frekuensi mencontek lebih kecil dibandingkan dengan siklus II. Dengan melakukan praktikum mahasiswa dapat menjawab permasalahan yang dihadapinya.

Berdasarkan data tersebut soal yang tentang pengamatan magnitude visual berkisar sebesar $71,4 \%$ dan ada $28,6 \%$ yang tidak sesuai. Untuk jawaban yang sesuai sebesar $62,8 \%$, dan yang tidak sesuai $37,2 \%$.

c) Tugas

Tugas ini sebagai upaya untuk mengembangkan pemahaman yang telah dimiliki mahasiswa dengan menerapkannya pada situasi yang berbeda. Mahasiswa meyelesaikan tugas yang dibuat oleh dosen. Dari kegitan ini, mahasiswa diharapkan dapat menyimpulkan kembali apa yang telah mereka pelajari.

Berdasarkan data tersebut, rata-rata nilai mahasiswa yang menjawab benar sebesar 89,16 dan rata-rata nilai jawaban yang salah 10,84 .

d) Pretest dan Posttest

Pada siklus III materi yang disajikan jumlahnya lebih banyak dibandingkan siklus II. Hasil evaluasi diberitahukan ke mahasiswa, sebagai umpan balik ke mahasiswa. Analisis hasil pretest dan posttest terdapat pada Tabel 3.

Tabel 3. Hasil Rekaman Pretest dan Posttest Siklus III

\begin{tabular}{llll}
\hline Pretest & Posttest & $\begin{array}{c}\text { Kenaikan } \\
\text { Pretest ke } \\
\text { Postest }\end{array}$ \\
\hline Rata-rata & 5,23 & 6,66 & 1,27 \\
\hline Nilai lebih dari 6 & $40,1 \%$ & $63 \%$ & $22,9 \%$ \\
\hline
\end{tabular}

Setelah dianalisis didapatkan data seperti pada tabel di atas. Skor pretest yang dicapai mahasiswa berkisar dari 2 sampai 8 , dan untuk skor posttest berkisar antara 3 dan 10, dengan kenaikan nilai rata-rata pretest ke nilai rata-rata posttest sebesar 1,27 . Sedangkan jumlah mahasiswa yang mendapatkan nilai 6 atau lebih, dari kegiatan pretest ke posttest mengalami kenaikan $22,9 \%$.

e) Lembar angket

Selain mengerjakan posttest, mahasiswa juga mengisi angket proses belajar mengajar yang telah mahasiswa ikuti. Berdasarkan hasil distribusi jawaban angket yang diperoleh menunjukkan bahwa mahasiswa yang senang sekali $9(23,68 \%)$ mahasiswa, mahasiswa yang senang 27 (71,06\%) mahasiswa, mahasiswa yang kurang senang $2(5,26 \%)$ mahasiswa, dan tidak ada $(0 \%)$ mahasiswa yang tidak senang.

Selama proses belajar mengajar juga teramati beberapa kejadian yang tercatat dalam jurnal harian. Berdasarkan wawancara dan diskusi dengan observer, mengatakan bahwa proses belajar mengajar pada siklus III sudah lebih baik, karena mahasiswa sudah terbiasa dengan proses belajar mengajar dengan learning cycle (daur belajar). Hal ini terlihat dengan aktivitas mahasiswa setiap tahapnya mengikuti dengan bebas, tidak merasa beban, hal ini nampak pada aktivitas praktikum, membuat soal beserta penyelesaiannya dan berdiskusi. Dari wawancara dengan mahasiswa, siswa merasa lebih senang belajar mengajar dengan praktikum dari pada mendengarkan ceramah dosen.

Permasalahan inti dalam proses pembelajaran adalah aktivitas belajar mahasiswa di kelas kurang aktif, akibat jarangnya penggunaan metode eksperimen. Adapun tujuan dari penelitian ini adalah mengembangkan format pembelajaran menggunakan pendekatan konstruktivistik melalui metode learning cycle untuk mengaktifkan mahasiswa dan meningkatkan penguasaan konsep. Sesuai dengan tujuan tersebut, maka penelitian ini merupakan penelitian tindakan yang terdiri dari tiga siklus tindakan. Adapun untuk setiap siklusnya, yaitu dengan memvariasi 
tahap-tahap dalam metode learning cycle. Pemberian variasi ini didasarkan pada hasil refleksi tindakan sebelumnya dan untuk memperbaiki proses belajar mengajsar.

Materi yang digunakan pada penelitian ini adalah pokok bahasan pengamatan benda langit, untuk siklus II dengan sub pokok bahasan penentuan bintang mati dan hidup, dan untuk siklus III dengan sub pokok bahasan magnitude visual.

Instrumen yang digunakan dalam penelitian ini adalah Satuan Acara Perkuliahan (SAP), lembar evaluasi, lembar soal dan penyelesaiannya, Lembar Kerja Mahasiswa (LKM), lembar observasi, angket, dan data pendukung lainnya seperti jurnal harian. Data yang dihasilkan dari instrumen tersebut dianalisis. Dari analisis data yang ada dapat dilihat dua keberhasilan proses belajar mengajar, yaitu keberhasilan proses dan keberhasilan produk.

\section{Keberhasilan Proses}

Keberhasilan roses dapat dilihat dari respon mahasiswa terhadap pelaksanaan proses belajar mengajar. Rekaman aktivitas siswa selama praktikum dan diskusi dari siklus I, II, dan III, dapat dilihat pada Tabel 4.

Tabel 4. Rekaman Aktivitas Siswa Siklus I, II, dan III

\begin{tabular}{lccc}
\hline \multicolumn{1}{c}{ Rekaman } & $\begin{array}{c}\text { Siklus } \\
\text { I }\end{array}$ & $\begin{array}{c}\text { Siklus } \\
\text { II }\end{array}$ & $\begin{array}{c}\text { Siklus } \\
\text { III }\end{array}$ \\
\hline $\begin{array}{l}\text { Aktivitas } \\
\text { Praktikum }\end{array}$ & $59,92 \%$ & $67,90 \%$ & $70,80 \%$ \\
\hline Bertanya & 5 & 9 & 14 \\
\hline Berpendapat & 9 & 13 & 15 \\
\hline
\end{tabular}

Dari tabel di atas bahwa dalam proses belajar mengajar ada peningkatan aktivitasm mahasiswa dari siklus I sampai III.

a. Pada tindakan siklus I, diawali dengan tahap melibatkan (engange) dosen berusaha menumbuhkan minat dan rasa ingin tahu mahasiswa dengan memberikan pretest ke mahasiswa dan menyampaikan Standar Kompetensi, Kompetensi Dasar, dan indikator untuk materi pelajaran yang akan dipelajari serta memberikan pengantar (apersepsi) yaitu dengan memberikan contoh dan pertanyaan secara lisan.
Adapun tahap mengungkapkan (explore), mahasiswa diberi kesempatan untuk memecahkan persoalan, yaitu melalui kegiatan praktikum. Sebelum melakukan praktikum, mahasiswa diberi kesempatan untuk mendesain percobaannya sendiri. Dengan data hasil percobaan mahasiswa menganalisis data tersebut dan berdiskusi kelompok, mahasiswa mengaitkan dengan masalah yang dihadapinya. Praktikum yang terlaksana pada tindakan I ini masih banyak mengalami kesulitan. Mahasiswa kurang berpengalaman dalam melakukan praktikum, sehingga masih banyak memerlukan bantuan dosen. Secara keseluruhan mahasiswa masih tergantung dari dosen, belum bisa menentukan sendiri, karena kerjasama antarmahasiswa masih kurang, sehingga hanya beberapa mahasiswa saja yang melaksanakan, sedangkan mahasiswa lainnya hanya menonton. Rekaman analisi lembar pengamatan aktivitas mahasiswa yaitu aktivitas mahasiswa selama praktikum berkisar dari 37,03\% sampai 92,59\% dan rata-rata aktivitas mahasiswa selama praktikum sebesar 59,92\%

Pada tahap menjelaskan (explain), mahasiswa melakukan diskusi klasikal. Kegiatan diskusi klasikal pada siklus I ini hanya diikuti oleh beberapa mahasiswa saja, bahkan untuk mengeluarkan pendapatnya, dosen menunjuk mahasiswa. Kebanyakan dari siswa masih bersifat pasif mendengarkan, sehingga dosen harus aktif memancing dan mengarahkan mahasiswa untuk aktif berdiskusi. Setelah diskusi, mahasiswa mendapatkan kebenaran jawaban atas permasalahan yang dihadapi pada tahap sebelumnya. Ketika diskusi klasikal siswa yang bertanya sebanyak 5 mahasiswa dan yang berpendapat/menjawab pertanyaan sebanyak 9 mahasiswa.

Untuk tahap mengembangkan (extend), mahasiswa secara berkelompok membuat soal dan yang menyelesaikannya mahasiswa, dimaksudkan agar mahasiswa berpikir kritis berdasarkan konsep yang telah diperolehnya. Pada tahap mengembangkan (extend) siklus I ini, dosen yang menentukan materi untuk soal yang 
akan dibuat. Hal ini dikarenakan mahasiswa kebingungan tentang merumuskan soal yang akan dibuat. Kejadian tersebut terjadi karena selama ini mahasiswa tidak terbiasa untuk membuat soal/mengungkapkan masalah-masalah yang ada disekitarnya. Pada kegiatan ini, sebagian mahasiswa terlihat hanya menonton saja. Selain membuat soal dan penyelesaiannya, mahasiswa juga mengerjakan posttest pada tahap mengembangkan (extend).

Keterlaksanaan dari hasil pengamatan aktivitas mahasiswa dan lembar observasi pada tindakan I, menunujukkan bahwa proses belajar mengajar belum bisa terlaksana dengan baik. Pelaksanaannya belum merata, mahasiswa masih sulit untuk bekerjasama, sehingga aktivitas selama proses belajar mengajar didominasi oleh beberapa mahasiswa tertentu dan mahasiswa masih bergantung pada dosen.

Pada tahap evaluasi (evaluate), data diperoleh dari hasil pekerjaan mahasiswa yaitu pretest, jawaban LKM, soal dan penyelesaian mahasiswa serta posttest dan jawaban angket yang diisi oleh mahasiswa untuk evaluasi proses pembelajaran.

b. Pada tindakan siklus II, kegiatan untuk tahap melibatkan (engange), dosen berusaha menumbuhkan minat dan membantu mahasiswa untuk mengakses pengetahuan awal mereka, yaitu dengan memberikan pretest dan menyampaikan Standar Kompetensi, Kompetensi Dasar, indikator untuk materi pelajaran yang akan dipelajari dan memberikan pengantar (apersepsi) dengan memberikan contoh dan setiap mahasiswa memunculkan permasalahan (membuat soal) berdasarkan tujuan setiap percobaan dan mahasiswa juga yang menjawabnya sesuai dengan pengetahuan awal yang dimilikinya. Pada tahap ini siswa mulai dapat merumuskan permasalahan, tidak bergantung pada dosen.

Adapun tahap mengungkapkan (explore), mahasiswa melakukan praktikum, tetapi sebelumnya mahasiswa mendesain percobaan terlebih dahulu. Mahasiswa sudah mulai lancar dan terbiasa dengan kegiatan praktikum. Hal ini terbukti mahasiswa tanpa menunggu perintah dari dosen langsung mengerjakan langkah yang pertama, yaitu mendesain percobaan. Selama mengikuti praktikum kerjasama antar mahasiswa dalam kelompok meningkat dibandingkan dengan siklus I. Hal ini terlihat dari distribusi kerja mahasiswa yang dilakukan selama praktikum yaitu berkisar dari $46,7 \%$ sampai $86,7 \%$. Dari rekaman tersebut pula dapat diungkapkan pula bahwa rata-rata aktivitas mahasiswa selama praktikum $69,53 \%$. Data hasil percobaan dianalisis kemudian didiskusikan secara kelompok untuk mendapatkan jawaban yang benar dari permasalahan yang dihadapinya.

Pada tahap menjelaskan (explain), mahasiswa melakukan diskusi klasikal. Untuk mengaktifkan mahasiswa dosen memberikan reward yaitu nilai plus bagi mahasiswa yang berani mengeluarkan pendapatnya. Beberapa mahasiswa mengikuti diskusi, mahasiswa bertanya dan mengeluarkan pendapatnya. Ketika dosen memberikan pertanyan-pertanyaan pancingan untuk mengarahkan mahasiswa membuat kesimpulan, mahasiswa menjawab bersahutan. Ketika diskusi klasikal mahasiswa yang bertanya sebanyak 9 mahasiswa dan yang berpendapat sebanyak 13 mahasiswa.

Tahap mengembangkan (extend), mahasiswa mengerjakan tugas dari dosen yaitu melengkapi pernyataan yang belum lengkap dan mahasiswa mengerjakan posttest

Tahap evaluasi (evaluate), merupakan tahap untuk mengevaluasi proses pembelajaran yang telah dilakukan, dimana datanya dari hasil pekerjaan mahasiswa yaitu pretest, jawaban LKM, soal dan penyelesaian, tugas serta posttest. Selain hasil pekerjaan mahasiswa juga dari angket yang telah diisi oleh mahasiswa.

Keterlaksanaan dari hasil pengamatan aktivitas mahasiswa dan lembar observasi pada tindakan II menunjukkan bahwa proses belajar mengajar sudah mulai terlaksana dengan baik. Mahasiswa sudah mulai aktif baik dalam praktikum maupun diskusi.

c. Pada tindakan III, tahap melibatkan (engange), yaitu dosen memberikan pretest dan menyampaikan Standar Kompetensi, 
Kompetensi dasar, indikator untuk materi pelajaran yang akan dipelajari dan memberikan pengantar dan mengaitkannya dengan pembelajaran sebelumnya. Tanpa menunggu perintah dosen, mahasiswa langsung membuat soal berdasarkan tujuan percobaan dan mahasiswa juga yang menjawabnya. Jumlah soal yang dibuat meningkat dibandingkan dengan siklus II.

Adapun tahap mengungkapkan (explore), diawali dengan mahasiswa mendesain percobaan. Kegiatan ini bagi mahasiswa, nampak sudah terbiasa. Hal ini terbukti tanpa menunggu perintah dari dosen langsung mengerjakan begitu setelah mendapat LKM. Dengan data hasil percobaan dan ringkasan materi (hand out), mahasiswa berdiskusi untuk menemukan jawaban yang benar atau memecahkan masalah yang dihadapi dari tahap sebelumnya. Selama kegiatan praktikum, kerjasama antar mahasiswa dalam kelompoknya meningkat dan mahasiswa sudah terbiasa dengan kegiatan praktikum. Dari rekaman tersebut distribusi kerja mahasiswa yang dilakukan selama praktikum yaitu berkisar dari 56,30\% sampai $87,50 \%$. dan dapat diungkapkan pula bahwa rata-rata aktivitas mahasiswa selama praktikum $67,90 \%$.

Pada tahap menjelaskan (explain), mahasiswa melakukan diskusi klasikal dengan ringkasan materi (hand out) sebagai pendamping diskusi (acuan). Selama diskusi mahasiswa mengikuti jalannya diskusi. Hal ini terbukti dengan meningkatnya mahasiswa yang berpendapat. Mahasiswa banyak yang mengacungkan jari mereka, sebagai tanda bahwa mahasiswa tersebut menginginkan untuk diberi kesempatan mengeluarkan pendapatnya maupun bertanya. Dari rekaman diskusi ini terungkap bahwa selama diskusi klasikal ini, ada 14 orang mahasiswa yang bertanya dan 15 orang mahasiswa mengemukakan pendapatnya.

Sedangkan untuk tahap mengembangkan (extend), mahasiswa secara kelompok berdiskusi untuk menyelesaikan tugas dari dosen. Setelah selesai mengerjakan tugas mahasiswa melakukan diskusi klasikal kembali untuk membahas lebih dalam dan menyimpulkan kembali apa yang telah dimilikinya. Kerjasama kelompok semakin meningkat dalam tahap ini, tidak ada mahasiswa yang ngobrol sendiri. Kegiatan akhir untuk tahap mengembangkan, yaitu mahasiswa mengerjakan posttest.

Tahap evaluasi (evaluate), merupakan tahap untuk mengevaluasi proses pembelajaran yang telah dilakukan. Keterlaksanaan dari hasil pengamatan aktivitas mahasiswa dan lembar observasi pada siklus III menunjukkan proses belajar mengajar sudah terlaksana dengan baik. Mahasiswa sudah terbiasa dengan kegiatan belajar mengajar dengan metode learning cycle. Hal ini terbukti dengan keaktifan mahasiswa mulai dari tahap engange (melibatkan) sampai tahap evaluate (evaluasi). Hal itu dapat terlihat dari rekaman aktivitas mahasiswa dan peningkatan jumlah soal yang dibuatnya, sedangkan hasil posttest mengalami penurunan, ini terkait dengan semakin kompleksnya materi yang dipelajari.

Dari siklus I, II, dan III dapat dilihat bahwa pada siklus III aktivitas mahasiswa dan respon mahasiswa lebih aktif. Hal ini terlihat dari rekaman aktivitas mahasiswa yang meningkat dan merata hampir pada semua siswa.

Langkah proses belajar mengajar pada siklus III, ini antara lain:

a. Tahap melibatkan (engange)

1) Dosen memberikan pretest ke mahasiswa.

2) Dosen menyampaikan Standar Kompetensi, Kompetensi Dasar, dan indikator untuk materi pelajaran yang akan dipelajari.

3) Dosen memberikan pengantar yaitu dengan memberikan contoh dan mengaitkannya dengan pembelajaran sebelumnya.

4) Mahasiswa merumuskan masalah/membuat soal berdasarkan tujuan percobaan dan menyelesaikannya sesuai dengan pengetahuan awal yang dimilikinya.

b. Tahap mengungkapkan (explore)

1) Mahasiswa melakukan praktikum dimana desain praktikum dibuat oleh 
JPFK, Volume 1, Nomor 1, Maret 2015 : 35 - 53

mahasiswa sendiri pada LKM yang telah disediakan.

2) Dengan data hasil percobaan dan membaca ringkasan materi (hand out), mahasiswa berdiskusi secara kelompok untuk mendapatkan kebenaran jawaban atas masalah yang dihadapi pada tahap sebelumnya.

c. Tahap menjelaskan (explain)

Diskusi klasikal dengan didampingi (acuan) ringkasan materi (hand out), untuk menyamakan pemahaman antarmahasiswa dan untuk merumuskan kesimpulan.

d. Tahap mengembangkan (extend)

1) Mahasiswa mengerjakan tugas dari dosen secara berkelompok, sebagai usaha untuk mengembangkan pemahaman yang telah dimiliki mahasiswa.

2) Diskusi klasikal untuk membahas lebih mendalam materi yang telah dipelajari dan siswa menyimpulkan kembali apa yang telah mahasiswa miliki.

3) Siswa mengerjakan posttest.

e. Tahap evaluasi (evaluate)

Evaluasi keseluruhan proses pembelajaran mengacu pada hasil pekerjaan mahasiswa yitu pretest, jawaban LKM, soal dan penyelesaian, tugas serta posttest. Selain hasil pekerjaan mahasiswa juga dari angket yang telah diisi oleh mahasiswa.

\section{Keberhasilan Produk}

Keberhasilan produk diperoleh dari hasil evaluasi mahasiswa. Evaluasi produk dapat dilihat dari LKM, lembar soal dan penyelesaiannya, tugas, pretest, dan posttest. Hasil pekerjaan mahasiswa dari LKM, lembar soal dan penyelesaiannya, tugas, pretest, dan posttest digunakan oleh dosen untuk menilai pembelajaran secara keseluruhan. Evaluasi ini menjadi umpan balik bagi dosen dalam memperbaiki proses belajar mengajar.

Berdasarkan hasil penelitian, persentase hasil rekaman LKM terdapat pada Tabel 5 berikut ini.
Tabel 5. Rata-rata Persentase Jawaban LKM RATA-RATA PERSENTASE JAWABAN

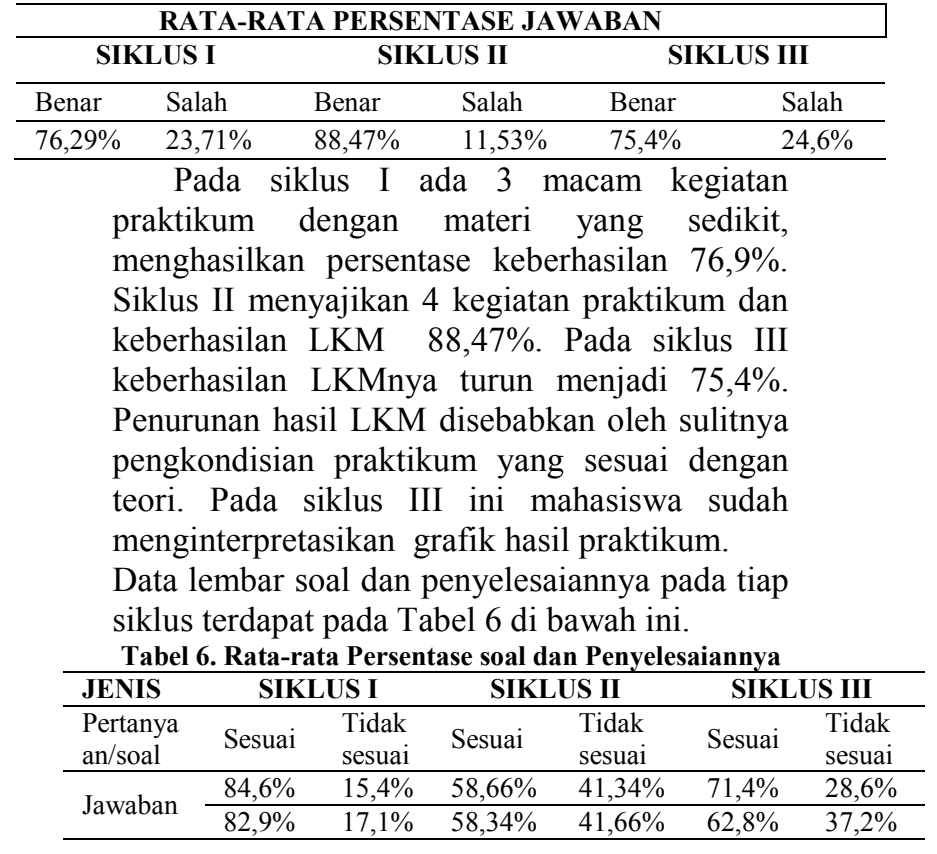

Berdasarkan data diatas dapat dilihat bahwa lembar soal dan penyelesaiannya untuk siklus I paling tinggi, hal ini karena materi soal ditentukan oleh dosen dan mahasiswa sudah mempelajarinya. Untuk siklus II persentase rata-rata dari soal dan penyelesaian sebelum praktikum dan sesudah praktikum, yang diperoleh ternyata lebih rendah daripada siklus I, hal ini karena mahasiswa sudah mulai mentukan soalnya sendiri, tidak bergantung pada dosen dan mahasiswa sudah mulai peka terhadap masalah-masalah di sekitarnya. Pada siklus III, prosentase soal lebih tinggi dibandingkan siklus II, ini menunjukkan bahwa mahasiswa semakin peka dengan masalah-masalah yang ada di lingkungannya. Mahaiswa semakin kritis dalam membuat pertanyaan, jumlah soal yang dibuat semakin meningkat.

Sedangkan data tugas pada tahap mengembangkan (extend), untuk siklus I dan II setelah dirata-rata, terdapat pada Tabel 7 dibawah ini :

\begin{tabular}{ccc}
\multicolumn{4}{c}{ Tabel 7. Rata-rata Nilai tugas } \\
\hline SIKLUS & RATA-RATA NILAI \\
\hline II & 91,82 & \\
\hline III & 89,16 & \\
\hline Untuk & pencapaian nilai dalam
\end{tabular}
penguasaan konsep fisika terlihat dari nilai yang diperoleh mahasiswa dalam tiap 
JPFK, Volume 1, Nomor 1, Maret 2015 : 35- 53

siklusnya. Rangkuman pencapaian nilai siswa tersaji dalam Tabel 8 .

Tabel 8. Rangkuman Pencapaian Nilai Mahasiswa pada Siklus I, II, dan III

\begin{tabular}{|c|c|c|c|c|c|c|}
\hline \multirow{2}{*}{ SIKLUS } & \multicolumn{3}{|c|}{ Rata-rata } & \multicolumn{3}{|c|}{ Nilai lebih dari $6(\%)$} \\
\hline & $\begin{array}{l}\text { Pre } \\
\text { test }\end{array}$ & $\begin{array}{l}\text { Post } \\
\text { test }\end{array}$ & Kenaikan & $\begin{array}{l}\text { Pre } \\
\text { test }\end{array}$ & $\begin{array}{l}\text { Post } \\
\text { test }\end{array}$ & Kenaikan \\
\hline I & 6,79 & 8,50 & 1,71 & 68,40 & 97,40 & 29 \\
\hline II & 6,32 & 9,37 & 3,05 & 56,4 & 100 & 43,6 \\
\hline III & 5,23 & 6,66 & 1,27 & 40,1 & 63 & 22,9 \\
\hline
\end{tabular}

Tabel di atas menunjukkan bahwa setiap siklus terjadi kenaikan nilai rata-rata dari pretest ke posttest. Pada siklus I dengan kenaikan nilai rata-rata 1,71 dan kenaikan jumlah mahasiswa yang mendapatkan nilai lebih dari 6 sebanyak $29 \%$, hal ini berarti pada pembelajaran siklus I cocok untuk mahasiswa yang mempunyai kemampuan sedang. Pada siklus II dengan nilai rata-rata 3,05 dan kenaikan jumlah mahasiswa yang mendapatkan mendapatkan nilai lebih dari 6 sebanyak 43,6\%, hal ini berarti pada pembelajaran siklus II cocok untuk siswa yang mempunyai kemampuan di bawah rata-rata. Untuk siklus III dengan nilai ratarata 1,27 dan kenaikan jumlah mahasiswa yang mendapatkan mendapatkan nilai lebih dari 6 sebanyak $22,9 \%$, hal ini berarti pada pembelajaran siklus III cocok untuk mahasiswa yang mempunyai kemampuan di atas rata-rata.

\section{KESIMPULAN}

Berdasarkan tujuan penelitian, hasil penelitian, dan pembahasan, maka penelitian ini dapat disimpulkan sebagai berikut:

1. Langkah-langkah penerapan pendekatan konstruktivistik melalui metode learning cycle, menunjukkan bahwa pembelajaran pada siklus ketiga paling efektif untuk mengaktifkan mahasiswa dalam proses belajar mengajar astrofisika. Langkah-langkah adalah sebagai berikut :

a. Tahap melibatkan (engange)

1) Dosen memberikan pretest ke mahasiswa.

2) Dosen menyampaikan Standar Kompetensi, Kompetensi Dasar, dan indikator untuk materi pelajaran yang akan dipelajari.
3) Dosen memberikan pengantar (apersepsi) yaitu dengan memberikan contoh dan mengaitkannya dengan pembelajaran sebelumnya.

4) Mahasiswa merumuskan masalah/membuat soal berdasarkan tujuan percobaan dan menyelesaikannya sesuai dengan konsep fisika yang dimilikinya.

b. Tahap mengungkapkan (explore)

1) Mahasiswa melakukan praktikum, dengan desain praktikumnya dibuat oleh mahasiswa sendiri pada LKM yang telah disediakan.

2) Dengan data hasil percobaan dan membaca ringkasan materi (hand $o u t$ ), mahasiswa berdiskusi secara kelompok untuk mendapatkan konsep yang benar atas masalah yang dihadapi pada tahap sebelumnya.

c. Tahap menjelaskan (explain) Diskusi klasikal dengan didampingi (acuan) ringkasan materi (hand out), untuk menyamakan pemahaman antar mahasiswa dan untuk merumuskan kesimpulan.

d. Tahap mengembangkan (extend)

1) Mahasiswa mengerjakan tugas dari dosen secara berkelompok, sebagai usaha untuk mengembangkan pemahaman yang telah dimiliki mahasiswa.

2) Diskusi klasikal untuk membahas lebih mendalam materi yang telah dipelajari dan mahasiswa menyimpulkan kembali apa yang telah mahasiswa miliki.

3) Mahasiswa mengerjakan posttest.

e. Tahap evaluasi (evaluate)

Evaluasi keseluruhan proses pembelajaran mengacu pada hasil pekerjaan mahasiswa yaitu pretest, jawaban LKM, soal dan penyelesaian, tugas serta posttest. Selain hasil pekerjaan mahasiswa juga dari angket yang telah diisi oleh mahasiswa.

2. Pendekatan konstruktivistik melalui metode learning cycle dapat meningkatkan penguasaan konsep fisika 
JPFK, Volume 1, Nomor 1, Maret 2015 : 35 - 53

pada mahasiswa. Pada siklus I menunjukkan peningkatan nilai rata-rata dari pretest 6,79 ke posttest 8,50 sebesar 1,71. Pada siklus II menunjukkan peningkatan nilai rata-rata dari pretest 6,32 ke posttest 9,37 sebesar 3,05. Pada siklus III menunjukkan peningkatan nilai rata-rata dari pretest 5,23 ke posttest 6,66 sebesar 1,27 .

\section{DAFTAR RUJUKAN}

Dryden. Gordon dan Jeanette Vos. (2000). Revolusi Cara Belajar (The Learning Revolution): Belajar akan Efektif kalau Anda dalam Keadaan "Fun"

Bagian I: Keajaiban Pikiran. Bandung: Kaifa.

Munjid Nur Alamsyah. (2003). Permasalahan yang Dihadapi Guru dalam Upaya Meningkatkan Kualitas Pembelajaran IPA di SMU. Yogyakarta: UNY.

Suwarsih Madya, dkk. (1994). Panduan Lembaga Penelitian Tindakan. Yogyakarta: Lembaga Penelitian IKIP Yogyakarta. 